2.

\title{
OPTIMIZATION OF REACTOR CONFIGURATION IN COAL LIQUEFACTION
}

NINTH QUARTERLY REPORT FOR THE PERIOD

1 OCTOBER 1993 - 31 DECEMBER 1993

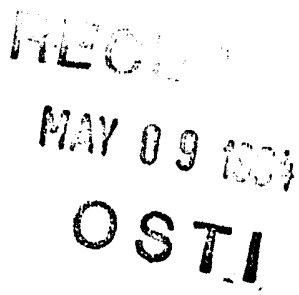

\author{
L.K. Lee \\ V.R. Pradhan \\ E.S. Johanson \\ A.G. Comolli \\ R.H Stalzer \\ DISCLAIMER
}

\begin{abstract}
This report was prepared as an account of work sponsored by an agency of the United States Government. Neither the United States Government nor any agency thereof, nor any of their employees, makes any warranty, express or implied, or assumes any legal liability or responsibility for the accuracy, completeness, or usefulness of any information, apparatus, product, or process disclosed, or represents that its use would not infringe privately owned rights. Reference herein to any specific commercial product, process, or service by trade name, trademark, manufacturer, or otherwise does not necessarily constitute or imply its endorsement, recommendation, or favoring by the United States Government or any agency thereof. The views and opinions of authors expressed herein do not necessarily state or reflect those of the United States Government or any agency thereof.
\end{abstract}

\section{WORK PERFORMED UNDER CONTRACT}

DE-AC22-91PC91052

HYDROCARBON RESEARCH, INC.

100 OVERLOOK CENTER, SUITE 400

PRINCETON, NJ 08540

\section{JANUARY 1994}

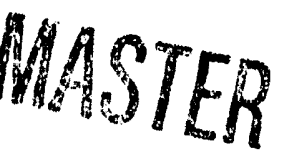


DOE-91052-9

OPTIMIZATION OF REACTOR CONFIGURATION IN COAL LIQUEFACTION

NINTH QUARTERLY REPORT FOR THE PERIOD

1 OCTOBER 1993 - 31 DECEMBER 1993

L.K. Lee

V.R. Pradhan

E.S. Johanson

A.G. Comolli

R.H Stalzer

DRAFT

WORK PERFORMED UNDER CONTRACT

DE-AC22-91PC91052

HYDROCARBON RESEARCH, INC.

100 OVERLOOK CENTER, SUITE 400

PRINCETON, NJ 08540

JANUARY 1994 


\section{TABLE OF CONTENT}

\section{Page}

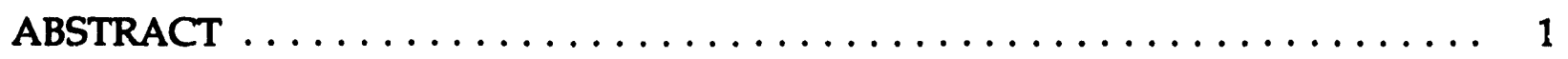

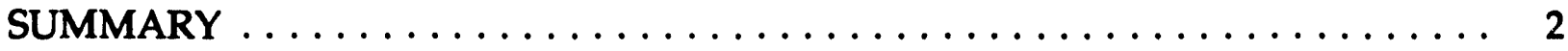

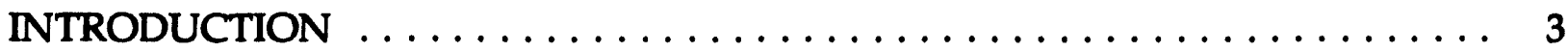

TASK 2 - LABORATORY SUPPORT $\ldots \ldots \ldots \ldots \ldots \ldots \ldots$

TASK 3 - LABORATORY SCALE OPERATIONS:

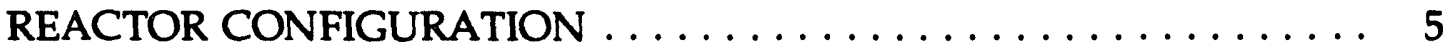

TASK $4-$ TECHNICAL ASSESSMENT $\ldots \ldots \ldots \ldots \ldots \ldots \ldots$

TASK 5 - PROJECT MANAGEMENT $\ldots \ldots \ldots \ldots \ldots \ldots \ldots$ 


\section{LIST OF FIGURES AND TABLES}

TABLES

TITLE

$\underline{\text { PAGE }}$

Table 1

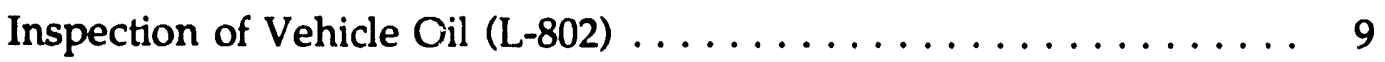

Table 2 Inspection of Illinois No. 6 Crown II Mine Coal . . . . . . . . . 10

Table 3 Simulated Three-Stage Liquefaction Run: Run Plan . . . . . . . 11

Table 4 Analysis of Fresh and Recovered AO-60 Catalyst . . . . . . . . 12

Table 5 Advanced Coal Liquefaction Program ................ 13

Table 6 Simulated Two-Stage Robinson-Mahoney Test (Run 245-22) . . . . . 14

FIGURES

TITLE

PAGE

Figure 1 A Schematic Process Diagram of the Two-Stage Robinson Mahoney Unit . . . . . . . . . . . . . . . . . . . . . 15

Figure 2 Run 245-22: K-1 and K-2 Internal Temperatures . . . . . . . 16

Figure 3 Run 245-22: K-1 and K-2 Skin Temperatures . . . . . . . . . 17

Figure 4 Run 245-22: Delta (Skin-Reactor Bottoms) Temperature . . . . . . 18 


\section{ABSTRACT}

This quarterly report covers the activities of Optimization of Reactor Configuration in Coal Liquefaction during the Period October 1 to December 31, 1993, at Hydrocarbon Research, Inc. in Lawrenceville and Princeton, New Jersey. This DOE Contract Period was from October 1, 1991 to September 30, 1993 and has recently been extended to March 31, 1994.

The overall objective of this program is to achieve a new approach to liquefaction that generates an all distillate product slate at a reduced cost of about $\$ 25$ per barrel of crude oil equivalent.

This quarterly report covers work on laboratory Support, Laboratory-scale Studies and Project Management. 


\section{SUMMARY}

During this reporting period, a simulated three-stage coal liquefaction continuous flow test was attempted using a two-stage Robinson-Mahoney reactor system. The objective of this test was to compare the performance of a two-stage fully backmixed system with a three-stage system with and without interstage stream re-concentration on processing Illinois No. 6 coal from Crown II Mine. Coal was fed continuously to the unit for 60 hours. However, due to mechanical problem encountered with the letdown and high differential temperature between the furnace and the reactor, the run was aborted.

The run will be repeated after modification on the letdown system has been completed. 


\section{INTRODUCTION}

This is the ninth progress report of a two-year contract to study and optimize various reactor configurations for direct coal liquefaction. The studies conducted during this quarter are reported by task.

Task 1 - Project Work Plan, had been completed.

Task 2- Laboratory Support, covers feedstocks characterization and general analytical supports for Task 3.

Task 3 - Laboratory-Scale Studies, evaluates three reactor configurations, namely, fixed-bed reactor as a "finishing reactor", three-stage close coupled backmixed reactor system and interstage product stream concentration.

Task 4 - Technical Assessment, includes modelling and comparative assessments of the three reactor configurations.

The Contract Period, which was originally from October 1, 1991 to September 30, 1993, has now been extended to March 31, 1994. 


\section{TASK 2 - LABORATORY SUPPORT}

Properties of the feed coal and vehicle oil used in the simulated three-stage run (245-22) are discussed.

\section{Vehicle Oil (L-802)}

The vehicle oil for the simulated three-stage test was a blend of makeup oil (L-794) and pressure filter liquids (L-795) from Bench Run 227-78 (CMSL-02). The blending ratio was 1 part of L-794 to 3 parts of L-795. Analysis of the composite oil, L-802, is given in Table 1. The composite oil contained $24.0 \mathrm{~W} \%$ of $524 \mathrm{C}$ (975F) residuum and $2.89 \mathrm{~W} \%$ of toluene insolubles.

\section{Feed Coal (HRI-6158)}

The feed coal was a bituminous coal, Illinois No. 6 Crown II Mine coal from Macoupin County. The pulverized coal was prepared by Empire Coke Company and shipped in nitrogen purged container truck to HRI for the Proof of Concept program. The drying was accomplished by hot inert gases containing less than $3 \mathrm{~W} \%$ oxygen. The analysis of a sample (HRI-6156) taken from a grinding test prior to the preparation of the bulk shipment is given in Table 2.

The feed coal contained 3-5 W\% of moisture. The characteristic of this coal was typical of Illinois No. coal. However, the chlorine content, $0.12 \mathrm{W \%}$, is considered to be in the high range. The total sulfur content was $4.48 \mathrm{~W} \%$, of which pyritic sulfur is slightly more than $25 \%$ ( $1.2 \mathrm{~W} \%$ maf coal).

The re-activity of the feed coal was tested under standard microautoclave conditions (Temperature of $427^{\circ} \mathrm{C}$ for 30 minutes under $13.8 \mathrm{MPa}$ of hydrogen over-pressure; solvent/coal/catalyst ratio of $4 / 1 / 1$ ). THF conversion ranged from 95.1 to $95.2 \mathrm{~W} \%$ was observed suggesting this coal is 3 to $3.5 \mathrm{~W} \%$ more active than previously tested Illinois No. 6 coals from Burning Star No. 2 Mine. 


\section{TASK 3 - LABORATORY SCALE OPERATIONS: REACTOR CONFIGURATION}

During this reporting period, a continuous flow test to evaluate the three stage reactor configuration and interstage stream concentration concept was attempted using a 1-liter two-stage Robinson-Mahoney reactor system. However, due to mechanical problem encountered, the test was aborted 60 hours after coal was introduced to the unit. An account of this attempt is described in this report.

\section{Objective}

To evaluate the three-stage and interstage stream concentration concepts using Ilinois No. 6 coal.

\section{Background}

The addition of a third back-mixed catalytic ebullated bed reactor in series to two closecoupled reactor will bring the performance of the process closer to the ideal plug flow configuration. An elementary first -order kinetic model, with equal temperatures in all stages, indicates that a three-stage system would require $26 \%$ less total volume than the two-stage configuration at a conversion level of $95 \%$.

The concentration of primary reactants declines progressively stage by stage in a closecoupled, multistage fully back-mixed system. More effective use of reactor space for the conversion liquid and solid phase reactants would be promoted if their concentrations in the liquid phase could be maintained at higher levels and the hydrogen partial pressure increased. Based on first-order kinetic model, it is projected that a three-stage system of back-mixed reactors with reconcentration of the second-stage product going to the third-stage require only $43 \%$ as much total reactor volume to attain $95 \%$ conversion as would be needed to a conventional two-stage system with no interstage feed concentration.

\section{Run Plan}

A two-stage Robinson-Mahoney reactor system was used for simulating the three-stage operations. The simulation will be achieved by two consecutive once-through tests. In the first test, two reactors will be used and the partially converted, slurry product from the this test will then served as feed material for the second test, which uses only a single reactor. 
This run consists of four operating conditions extending over a 16 days duration, as shown in Table 3. Conditions 1 one of the two conditions to be evaluated in is the first half of the non-integrated three-stage test with the first and second temperature to be controlled at 399 and 429 C, respectively. The slurry product from Condition 1 will then be further processed in Conditions 3 and 4 (the second half of the test), with or without removal of lighter product. Process conditions chosen for Condition 2 are typical CTSL operating conditions. The process performance from Condition 2 serves as a basecase for comparing with the simulated three-stage operations Condition 1-3 and Condition 1-4.

\section{Robinson-Mahoney Reactor}

The Robinson-Mahoney dual-reactor system, employed for this coal liquefaction study, was supplied by Autoclave Engineering, Inc. With the exception of the stationary catalyst cage, the internals of the reactor were the original design. The cage was modified to hold approximately $128 \mathrm{cc}$ of extrudate catalysts by increasing the wide of the annulus space. Heat is provided by a single zone $1.7 \mathrm{Kw}$ electric furnace. The reactor internal temperatures are measured at two locations $(14$ and $19 \mathrm{~cm}$. below the top flange).

The top and the body flanges were insulated to minimize the heat lost through the top section, the unheated section, of the reactor. In spite of this effort, the temperature gradient in the vapor phase was as great as $2.5-2.8^{\circ} \mathrm{C} / \mathrm{cm}(12-13 \mathrm{~F} / \mathrm{in}$.). The agitation speed was $1200 \mathrm{rpm}$.

A schematic process flow diagram is shown in Figure 1. The vehicle oil, feed coal and hydrogen are mixed and preheated to about $344 \mathrm{C}$ before entering the first reactor through a bottom port. The gas/liquid interface is controlled by the height of an overflow tube. The interface is usually slight above the overflow tube as suggested by reactor axial temperature profiles measured under system pressure and temperature.

\section{Feed Coal and Vehicle Oil}

Illinois No. 6 coal from the Crown II Mine was used in this test. This coal was also used in the Proof of Concepts program (POC-01). The vehicle oil was a blend of makeup oil (L-794) and pressure filter liquids (L-795) from Bench Run 227-78 (CMSL-02). The analysis of the feed coal and vehicle oil is given in Table 1. 


\section{Operating Summary}

Run preparation started on November 12, 1993. Each of the two reactors was charged with 128 cc of Akzo AO-60 1/16" extrudate catalyst recovered from the first stage of Bench Run 227-76 (CC-16). The characteristics of the fresh and recovered catalysts are compared in Table 3. The recovered catalyst contained $12.4 \mathrm{~W} \%$ of carbon and $1.94 \mathrm{~W} \%$ of metal contaminants. Also, the surface area was reduced from $286 \mathrm{~m}^{2} / \mathrm{g}$ in the fresh catalyst to $189 \mathrm{~m}^{2} / \mathrm{g}$ in the recovered catalyst.

The unit was heated up on No. 2 fuel oil on November 15; switched to startup oil L-769 and followed by L-802, the vehicle oil, as the reactor temperatures approaching the desired steady temperature for Condition 1 . Coal feed was introduced to the system at 2400 hours of November 16. Coal feed was maintained for about 60 hours prior to shutdown which was caused by high furnace temperature required to sustain the desired temperature in second stage reactor. Also, as a result of failures of letdown valve several system upsets, loss of pressure ranging from 3.5-13.8 $\mathrm{MPa}(500-2000 \mathrm{psi})$ were experienced during this operating periods. However, four 12-hour material balance periods were completed.

Unit inspection indicated the following:

1. Both the first and second stage reactors had approximately $1 / 2$ " thick layer of some unreacted coal or coke deposits on top of the catalyst cages. The thermowell and the agitator were also covered with dry coke-like solids.

2. The agitator blade assembly became disengaged from the magnetic drive. The agitator would not turn with the magnetic drive.

Temperature in both reactor was very stable in the first 24 hours of operator on coal feed. Reactor 1 temperature was controlled well between the range of 399-405C, while Reactor 2 temperature was within a tighter range 426-430C. Approximately, 25 hours on coal feed both reactor temperatures started to decrease, while the external furnace temperature took a step jump of $20-25 \mathrm{C}$ and then increased steadily thereafter. The sudden increase in the differential temperature between the furnace and the reactor liquid at 25-28 hours suggested either a fast buildup of solid materials on the reactor well or/and the loss of mixing in the reactors. 


\section{Material Balance and Product Inspection}

Table 5 summarizes the input rates, output rates and yield of net products for the four material balance periods. With the exception of sub-period $2 \mathrm{~B}$, the overall mass recoveries were within 94.0 to $101.0 \mathrm{~W} \%$. The mass balance of sub-period $2 \mathrm{~B}$ was very poor (79.2 W\%). A significant amount of the Separator Overhead and Bottom products were not accounted for in this sub-period.

Products form the Period 2B are being analyzed and preliminary results are listed in Table 6. The coal conversion was estimated to be $92.6 \mathrm{~W} \%$. The conversion level approaches the highest value of $96.0 \mathrm{~W} \%$ observed in a larger scale two-stage operation (PDU) at higher reaction severity of 413 and $433 C$.

\section{Recommendations and Future Plan}

The simulated three stage run will be repeated in late February or early March time frame. Prior to the repeated test the existing stellite trim on the Hot Separator letdown valve will be replaced by tungsten carbide. Also, a short series of cold model study is planned to evaluate the solid and liquid mixing pattern in the reactor using a "see through" mockup model.

\section{TASK 4 TECHNICAL ASSESSMENT}

No activity was undertaken during this reporting period.

\section{TASK 5 PROJECT MANAGEMENT}

Updated work schedule is attached (Figure 2) 
Table 1

Inspection of Vehicle Oil (L-802)

API Gravity

ASTM-D1160 Distillation

IBP
5 V\%
10 V\%
$13 \mathrm{~V} \%$
$20 \mathrm{~V} \%$
$30 \mathrm{~V} \%$
$40 \mathrm{~V} \%$
$50 \mathrm{~V} \%$
$60 \mathrm{~V} \%$
$64 \mathrm{~V} \%$
$70 \mathrm{~V} \%$
$78 \mathrm{~V} \%$

Distribution

IBP-343C

$343-454 \mathrm{C}$

$343-524 \mathrm{C}$

$524 \mathrm{C}+$

Elemental Analysis [W\%]

Carbon

87.95

Hydrogen

Nitrogen

Sulfur

0.36

0.21
7.8

[C] [F]

$82 \quad 179$

$224 \quad 435$

$329 \quad 625$

$343 \quad 650$

$349 \quad 660$

$373 \quad 704$

$391 \quad 735$

$409 \quad 769$

$438 \quad 820$

$454 \quad 850$

$468 \quad 875$

$524 \quad 975$

W\% V\%

$12.69 \quad 13$

$48.23 \quad 51$

$15.06 \quad 14$

Solubility [W\%]

Cyclohexane Insol. $\quad 6.73$

Toluene Insol.

2.89 


\section{Table 2}

\section{Inspection of Illinois No. 6 Crown II Mine Coal}

$\begin{array}{lc}\text { Moisture, W\% } & 3.39 \\ & \\ \text { Proximate Analysis, W\% dry basis } & \\ \text { Volatile Matter } & 41.40 \\ \text { Fixed Carbon } & 49.18 \\ \text { Ash } & 9.42 \\ & \\ \text { Elemental Analysis, W\% dry-ash free basis } \\ \text { Carbon } & 79.32 \\ \text { Hydrogen } & 5.85 \\ \text { Nitrogen } & 1.58 \\ \text { Sulfur } & 4.48 \\ \text { Oxygen (by diff.) } & 8.77 \\ \text { Chlorine } & 0.12 \\ \text { H/C } & 0.89\end{array}$

Sulfur Forms, W\% dry-ash free basis

Sulfate

Pyritic

1.00

Organic

Mineral Analysis, W\% Ash

$\begin{array}{lr}\mathrm{P} 2 \mathrm{O} 5 & 0.23 \\ \mathrm{SiO} 2 & 49.98 \\ \mathrm{Fe} 2 \mathrm{O} 3 & 16.34 \\ \mathrm{Al} 2 \mathrm{O} 3 & 18.64 \\ \mathrm{TiO} 2 & 0.95 \\ \mathrm{CaO} & 4.05 \\ \mathrm{MgO} & 0.87 \\ \mathrm{SO} 3 & 3.38 \\ \mathrm{~K} 2 \mathrm{O} & 2.27 \\ \mathrm{Na} 2 \mathrm{O} & 1.48 \\ \mathrm{SrO} & 0.03 \\ \mathrm{BaO} & 0.01 \\ \mathrm{Mn3O} 4 & 0.10 \\ \text { Underdetermined } & 1.67\end{array}$


Table 3

Simulated Three-Stage Liquefaction Run: Run Plan

Illinois No. 6 Coal (HRI-6107)

Shell S-317 Ni/Mo 1/32" Catalyst (HRI-5394)

\begin{tabular}{|c|c|c|c|c|}
\hline $\begin{array}{l}\text { Condition } \\
\text { Periods }\end{array}$ & $\begin{array}{l}1 \\
1-8\end{array}$ & $\begin{array}{l}2 \\
9-11\end{array}$ & $\begin{array}{l}3 \\
12-14\end{array}$ & $\begin{array}{l}4 \\
15-16\end{array}$ \\
\hline No. of Reactor & 2 & 2 & 1 & 1 \\
\hline \multicolumn{5}{|l|}{ Temperature, ${ }^{\circ} \mathrm{F}$} \\
\hline $\begin{array}{l}\text { Reactor \#1 } \\
\text { Reactor \#2 }\end{array}$ & $\begin{array}{l}750 \\
805\end{array}$ & $\begin{array}{l}750 \\
825\end{array}$ & $\begin{array}{l}825 \\
n / a\end{array}$ & $\begin{array}{l}825 \\
n / a\end{array}$ \\
\hline $\begin{array}{l}\text { Space Velocity } \\
\text { Ib MAF coal/h/ft } \\
\text { cat. per } 1 \text { st stage }\end{array}$ & 66 & 44 & 66 & 66 \\
\hline Solvent/Coal Ratio & Coal & Coal & $\begin{array}{l}\text { Cond. } 1 \\
\text { Whole } \\
\text { Product } \\
\text { n/a }\end{array}$ & $\begin{array}{l}\text { Cond. } 1 \\
\text { Topped } \\
\text { Product } \\
\text { n/a }\end{array}$ \\
\hline
\end{tabular}

Coal and Solvent Flowrates:

\section{Pat I}

dry coal, $g / h$

wet coal, $g / h$

@ 3W\% moisture $\quad 140$

solvent, $g / h$

Total Slurry, g/h

Part II

Slurry, (dry) $g / h$

Water,g/h
136

168

308

90

n/a

n/a

Hydrogen and Water Injection Rates:

Hydrogen, scth 11

7.0

8.0

8.0

$\begin{array}{llll}n / a & n / a & 195^{*} & 210^{* *} \\ n / a & n / a & 21^{*} & n / a\end{array}$

- To be confirmed to match the production rate of separator bottoms from Condition \#1.

* To match the production of topped separator bottoms from Condition \#1 
Table 4

\section{Analysis of Fresh and Recovered AO-60 Catalyst}

Catalyst

Catalyst Age, $\mathrm{Kg}$ coal $/ \mathrm{Kg}$ cat.

Bulk Density, gm/cc

Analyses of Oil Free +20 mesh Catalyst, W\%

Carbon

Hydrogen

Nitrogen

Sulfur

H/C Ratio

Molybdenum

Nickel

Titanium

Iron

Calcium

Sodium

Total Metal Contaminants

Loss on Ignition, W\%

Particle Density, gm/cc particle*

Pore Volume, cc/gm

Surface Area, $\mathrm{m} 2 / \mathrm{gm}$

Modal Pore Diameter, Angstrom

Macropores

Mesopores
Fresh

0

0.557

12.43

0.90

0.32

5.59

0.87

12.25

2.60

7.59

1.80

1.021

0.372

0.056

0.493

1.94

20.82

3.547

0.874

286

2.412

0.489

190

875

125

80 


\section{Table 5}

\section{Advanced Coal Liquefaction Program \\ Simulated Three-Stage Continuous Flow Test}

Part I Condition I

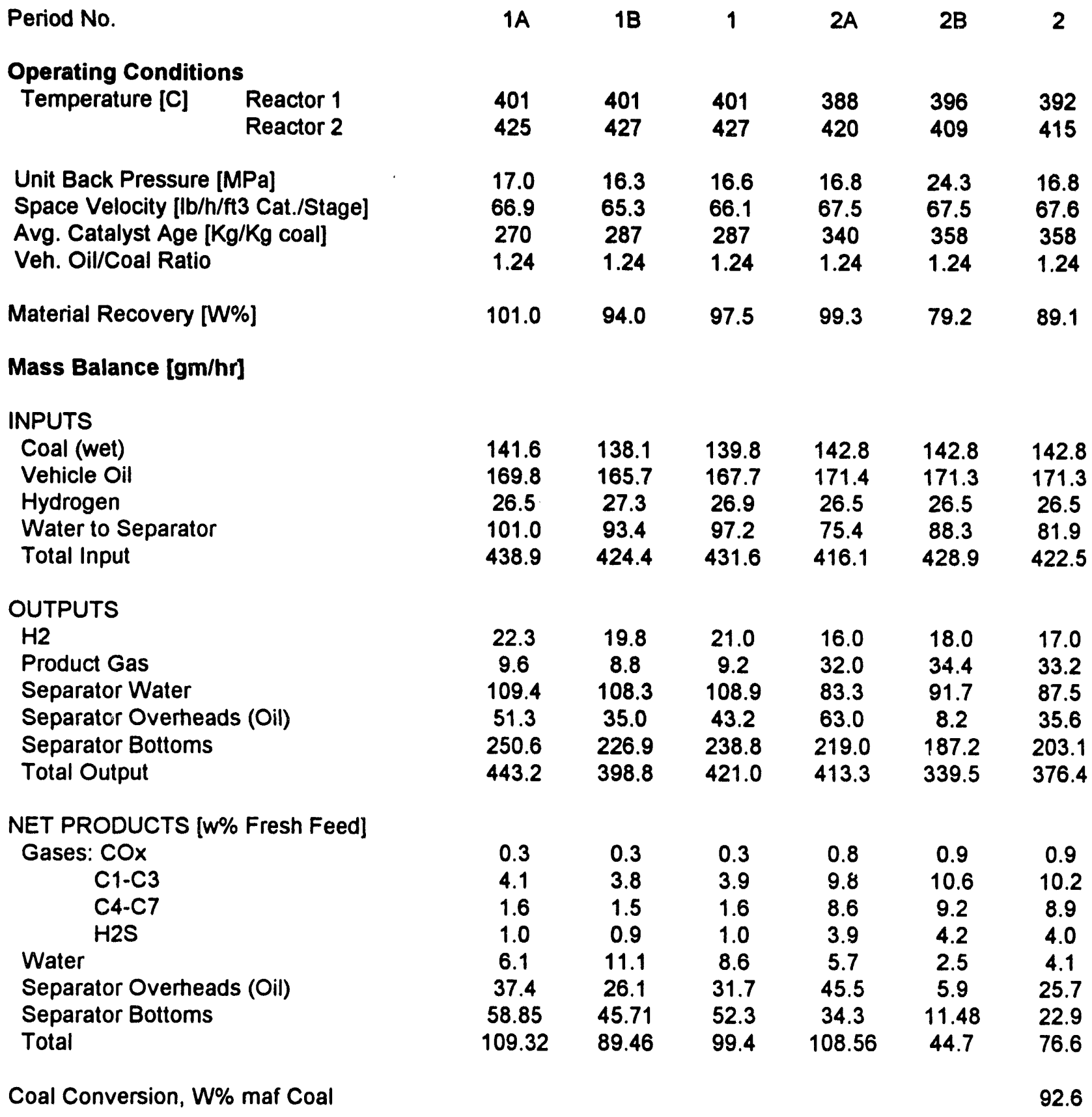


Table 6

Simulated Two-stage Robinson Mahoney Test (Run 245-22)

Inspection of Separator Bottoms

Pressure Filuration:

Filter Liquids:

83.19 W\%

Solids:

$16.81 \mathrm{~W} \%$

Pressure Filtered Liquid

\begin{tabular}{cc} 
API & 7.6 \\
IBP [C] & 226 \\
& \\
IBP-343C & W\% \\
\hline $343-454 C$ & 23.01 \\
$343-524 C$ & 41.20 \\
$524 C+$ & 12.68 \\
& 23.11
\end{tabular}

Filter Cake

Quinoline Insolubles

Ash in QI

$\frac{\mathbf{W} \%}{29.73}$

Sulfur in QI Ash

17.99

0.94

Coal Conversion

92.6

Whole Sample

IBP-343C
$343-454 C$
$343-524 C$
$524 C+$
Unreacted Coal
Ash

$\frac{\text { W\% }}{21.86}$

39.14

12.05

21.95

1.97

3.02 


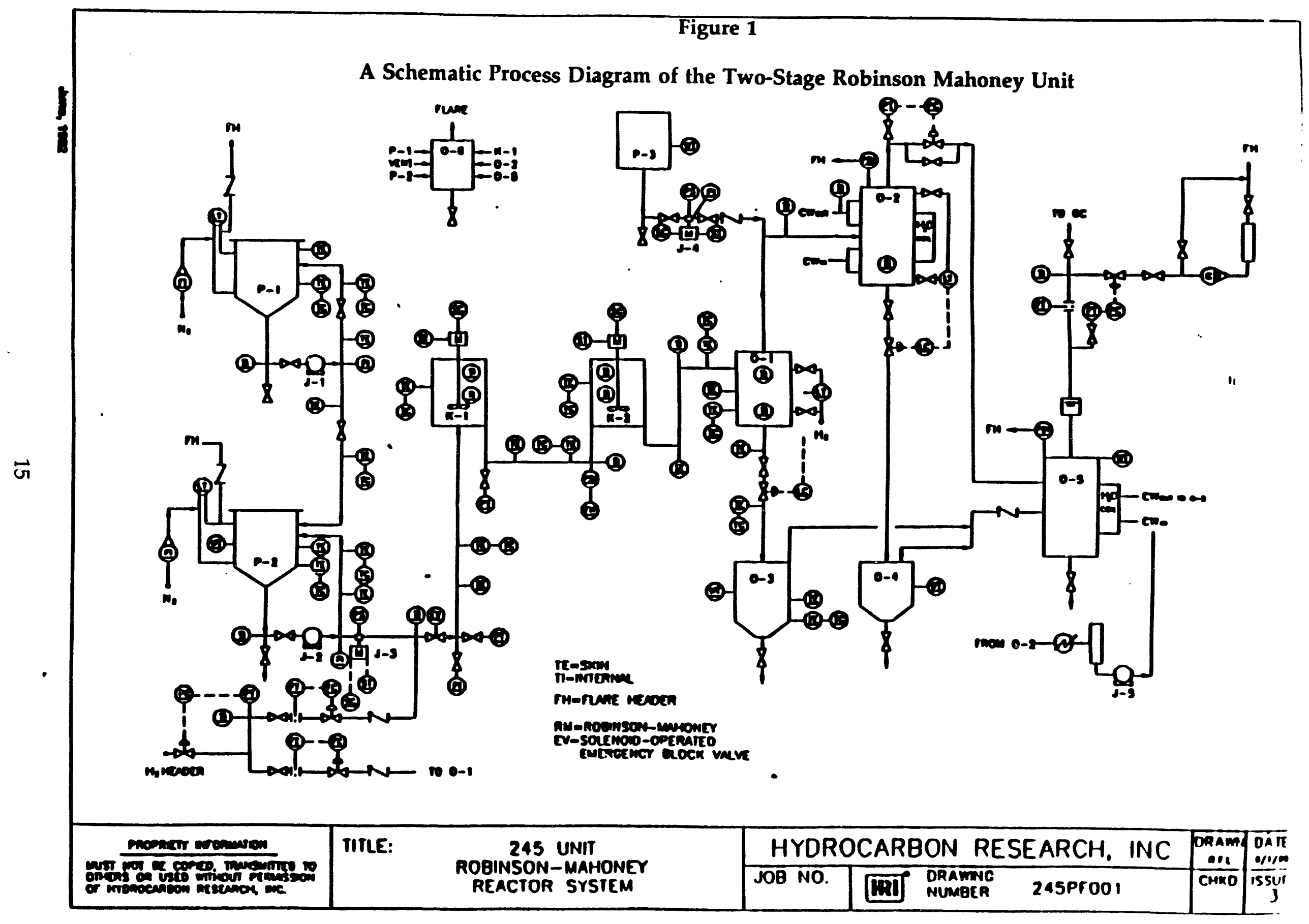


Figure 2

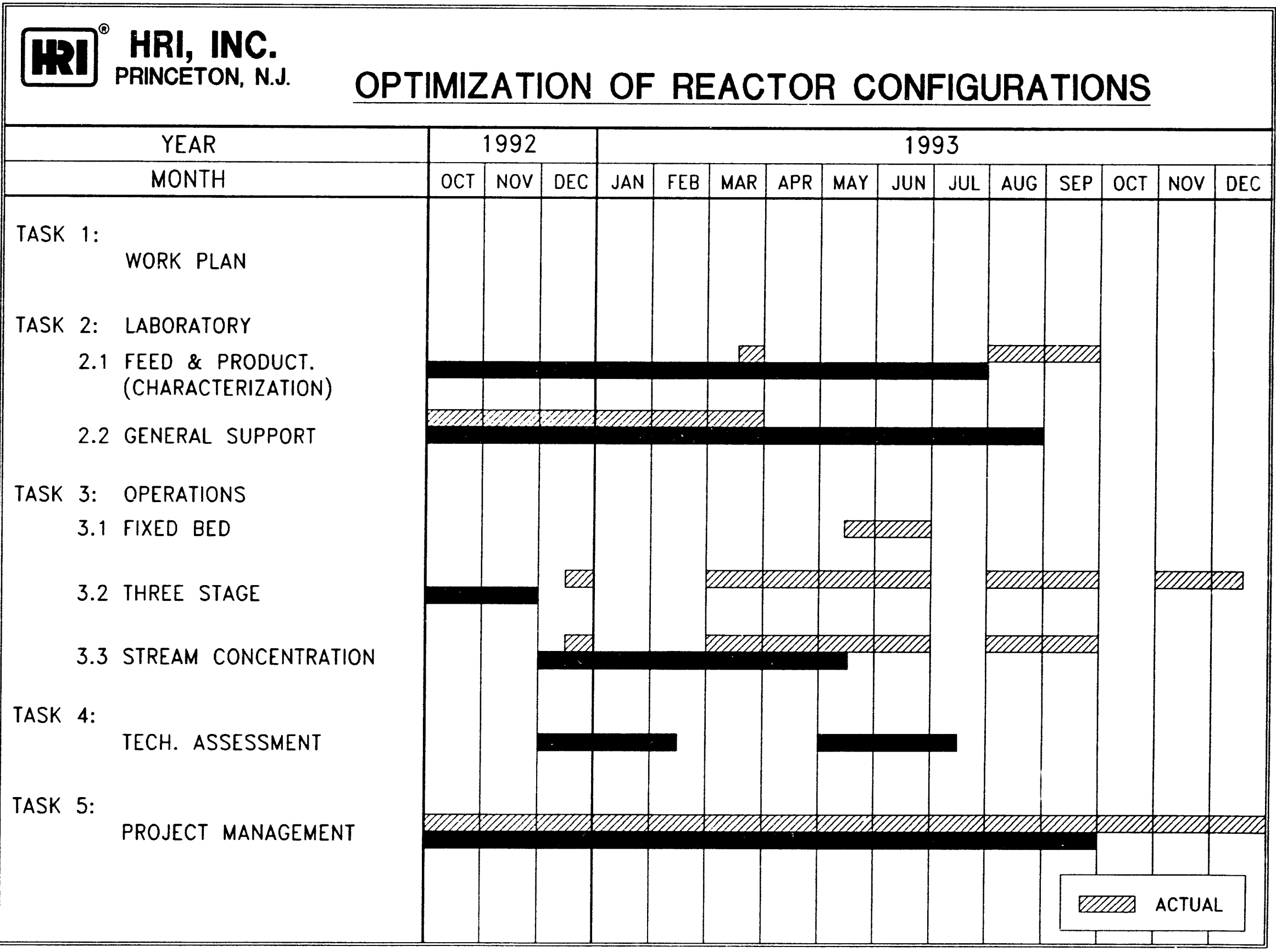



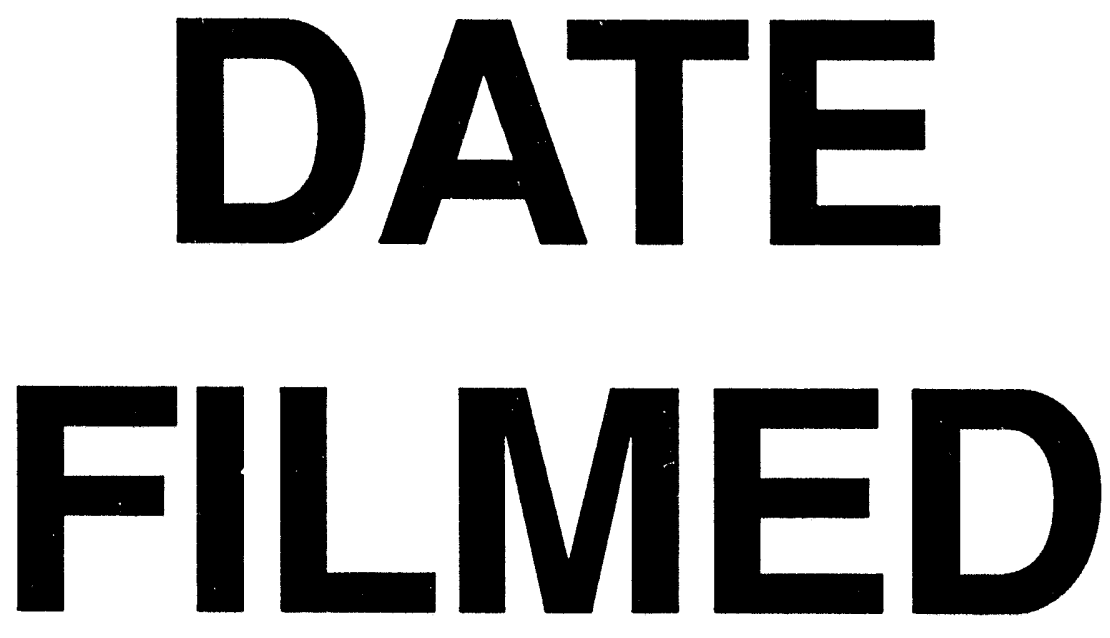

$6 / 1 / 94$
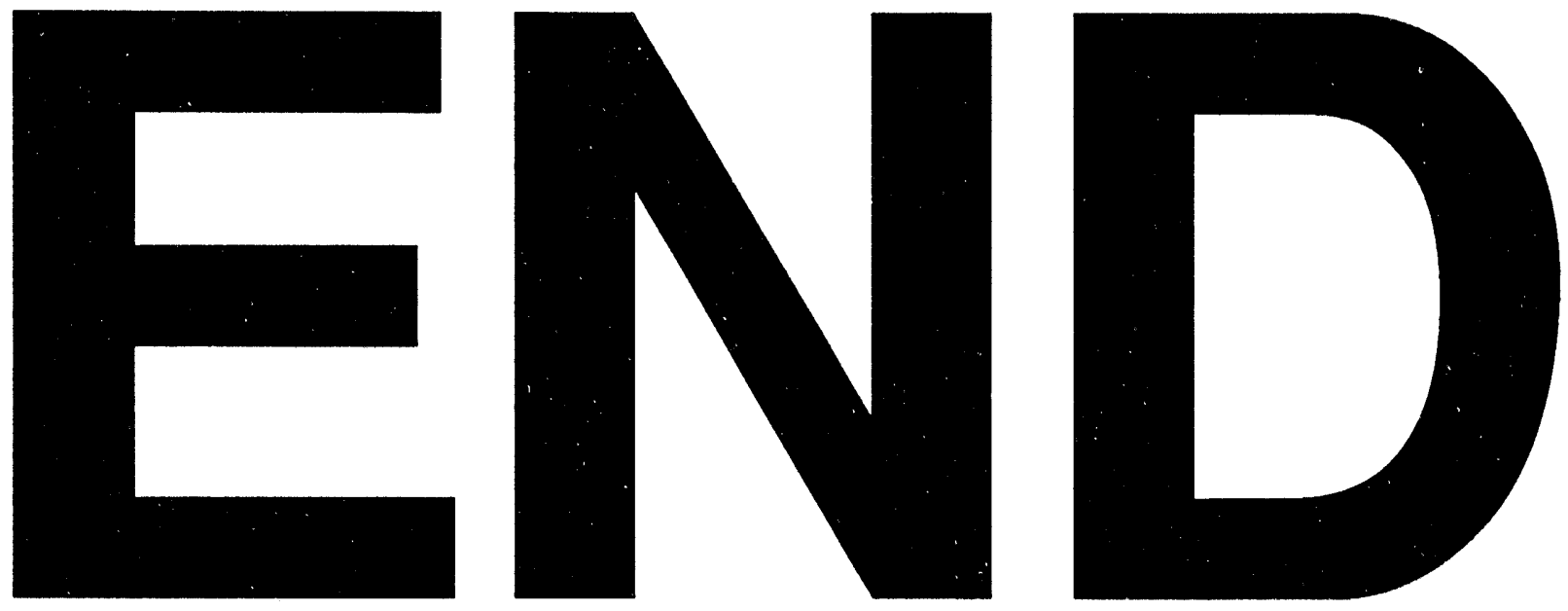
